\title{
TILIA'S PHYSICAL DIMENSIONS OVER TIME
}

\author{
by Flemming Kjølstad Larsen ${ }^{1}$ and Palle Kristoffersen ${ }^{2}$
}

\begin{abstract}
Tree height, trunk height, trunk diameter, crown base, and crown radius were measured on 331 trees growing in urban environments (Tilia cordata, T. europaea, T. euclora, and $T$. platyphyllos). Regression analyses revealed quadratic correlation between age and size for all relationships. Growth formulas and growth rates were derived and growth curves compiled. The results can be used for forecasting Tilia's physical dimensions as functions of time and environment and with it for planning and assessing the consequences of Tilia tree-planting schemes in urban environments. When implemented as a computer-aided design (CAD) application, these relationships can form the basis for dynamic illustration of a project.
\end{abstract}

Key Words. Tilia; computer-aided design; urban trees; tree growth.

All architectural uses of trees must fulfill spatial and aesthetic functions. The visual impression is vital because first impressions are based on what we see, with size and form as the dominant factors. Purposeful work with design of urban tree schemes demands a thorough knowledge of individual species' growth potential in relation to the given growing environment.

This study describes and determines the relationships between age and tree height, age and trunk height, age and trunk diameter, age and crown base, age and crown radius, and for unshaded trees and trees with their crowns affected by shading, when their crowns are growing together.

The purpose of this study is to make it possible at any given time to forecast the dimensions of the trees as functions of age. It should be possible to use this tool to estimate the consequences of planting grids, and in landscape design, to provide the information needed for better, more realistic planting plans. When implemented as a computer-aided design (CAD) application, these relationships can form the basis for the dynamic illustration of a project.

\section{MATERIALS AND METHODS}

The data were recorded in Copenhagen, Denmark, $55^{\circ}$ $42^{\prime} \mathrm{N}, 12^{\circ} 35^{\prime} \mathrm{E}$. Copenhagen is characterized by a coastal climate. All measurements were carried out on trees that seemed undamaged and unrestricted by wind.

The data were recorded during the period February through April 1997. It covers 331 Tilia (T. cordata, T. europaea, T. euclora, and T. platyphyllos), which were distributed as 251 trees at 25 locations in rows along streets, supplemented by measurements taken from 80 trees in nurseries (Table 1). All were chosen in light of age, with a view toward describing growth throughout the chosen period of 0 to 100 years.

The ages of the plantations were calculated from park administrations' plant records. If tree size at the time of establishment was not known, then 10 years, which corresponds to a trunk circumference of 18 to $20 \mathrm{~cm}$ (7 to 8 in.), was added to the age.

A number of trees representative of each plantation were chosen and measured (Table 1). The choices were made on the basis of the visual impression of the trees' dimensions. Extremes were excluded (e.g., extremely small trees, damaged trees). The distances between rows and plants were measured with a tape measure and were specified as the average of at least three measurements, rounded off to the nearest $5 \mathrm{~cm}$ ( 2 in.). Tree height, trunk height (from the ground to the bottom of the first influential branch), and crown base height (from the ground to underneath of the crown) were measured by clinometric triangulation and rounded off to the nearest $5 \mathrm{~cm}$. Trunk diameters were calculated from the external trunk circumference, as measured with a tape measure at a height of $1 \mathrm{~m}(3.3 \mathrm{ft})$ (relating them to Danish commercial sizes) and rounded off to the nearest whole centimeter. Crown radii were measured along the ground surface with a tape measure from the center of the trunk to the tip of the most remote downward-projecting shoot, rounded off to the nearest $5 \mathrm{~cm}$. 
Table 1. Age and size measurements of four Tilia species.

\begin{tabular}{|c|c|c|c|c|c|c|c|c|}
\hline \multirow[b]{2}{*}{ Species/location } & \multirow{2}{*}{$\begin{array}{l}\text { Number } \\
\text { of trees }\end{array}$} & \multirow{2}{*}{$\begin{array}{l}\text { Age } \\
\text { year }\end{array}$} & \multicolumn{2}{|c|}{ Tree height $(\mathrm{m})$} & \multicolumn{2}{|c|}{ Trunk height $(\mathrm{m})$} & \multicolumn{2}{|c|}{ Trunk diameter $(\mathrm{cm})$} \\
\hline & & & Average & $\mathrm{SD}^{z}$ & Average & $\mathrm{SD}^{\mathrm{z}}$ & Average & $\mathrm{SD}^{\mathrm{z}}$ \\
\hline \multicolumn{9}{|l|}{ T. cordata } \\
\hline Bellahoejparken & 10 & 32 & 9.23 & 0.85 & 6.62 & 0.70 & 21.77 & 1.93 \\
\hline Irlandsvej II & 10 & 20 & 8.62 & 1.37 & 5.94 & 0.86 & 14.39 & 2.65 \\
\hline Landgreven & 10 & 48 & 12.44 & 1.73 & 9.24 & 1.59 & 26.87 & 2.72 \\
\hline Birkholm $^{x}$ & 10 & 8 & 3.89 & 0.47 & 2.06 & 0.15 & 5.35 & 0.39 \\
\hline Borgervænget I & 10 & 95 & 16.46 & 1.95 & 12.22 & 1.74 & 57.52 & 4.24 \\
\hline Borgervænget II & 10 & 33 & 7.28 & 0.64 & 4.77 & 0.58 & 14.01 & 1.06 \\
\hline \multicolumn{9}{|l|}{ T. europaea } \\
\hline Allersgade & 10 & 24 & 9.55 & 0.53 & 7.18 & 0.61 & 19.19 & 3.70 \\
\hline Allersgd.-Thorsgd. & 10 & 24 & 7.63 & 0.60 & 5.00 & 0.80 & 14.77 & 1.31 \\
\hline Kastrup Fort & 10 & 25 & 10.11 & 0.57 & 7.07 & 0.72 & 25.69 & 2.94 \\
\hline Noerre Allé & 10 & 17 & 8.50 & 0.84 & 5.51 & 0.80 & 19.70 & 4.06 \\
\hline Noerrebroparken & 10 & 65 & 18.92 & 0.95 & 15.27 & 1.66 & 51.73 & 3.53 \\
\hline Remiseparken & 12 & 40 & 9.42 & 0.60 & 6.80 & 0.68 & 24.14 & 3.42 \\
\hline Ryvang Allé & 10 & 105 & 17.81 & 1.26 & 13.64 & 1.17 & 53.32 & 4.99 \\
\hline Roedkilde Plads & 10 & 82 & 20.53 & 0.69 & 16.00 & 0.96 & 50.58 & 4.40 \\
\hline Roedovre Raadhus & 8 & 51 & 11.27 & 0.44 & 8.65 & 0.63 & 27.22 & 4.37 \\
\hline Stengade & 10 & 26 & 9.89 & 0.82 & 7.72 & 0.92 & 18.75 & 1.62 \\
\hline Soendermarken & 10 & 39 & 15.21 & 0.98 & 11.86 & 0.91 & 33.30 & 2.21 \\
\hline Ulrich Birks Allé & 10 & 107 & 18.39 & 1.67 & 14.85 & 1.82 & 63.44 & 7.44 \\
\hline Vestre Kirkegaard & 12 & 112 & 25.09 & 1.67 & 20.62 & 2.28 & 53.58 & 17.33 \\
\hline \multicolumn{9}{|l|}{ T. platyphyllos } \\
\hline Fælledparken & 10 & 31 & 9.56 & 1.88 & 7.20 & 1.89 & 26.04 & 5.16 \\
\hline Hulgaards Plads & 9 & 60 & 14.94 & 1.78 & 12.05 & 1.62 & 49.06 & 6.11 \\
\hline Lyngbyvej & 10 & 31 & 9.09 & 1.05 & 6.17 & 1.14 & 22.00 & 1.71 \\
\hline
\end{tabular}

${ }^{2}$ Standard deviation.

${ }^{\mathrm{x}}$ Trees in nurseries. 
Table 2. Growth rates of Tilia cordata, T. europaea, and T. platyphyllos.

\begin{tabular}{lll}
\hline$Y^{*}$ & $b_{1}$ & $b_{2}$ \\
\hline Tree height & 0.3846 & -0.0038 \\
Trunk height & 0.1061 & -0.0012 \\
Trunk diameter & 0.8778 & -0.0066 \\
Crown base & 0.0891 & -0.0010 \\
Crown radius, unshaded & 0.1257 & -0.0010 \\
Crown radius, shaded & 0.1358 & -0.0016 \\
\hline
\end{tabular}

${ }^{*} Y=b_{1} d+b_{2} d ; d=$ age.

The variability for each plantation was examined and considered homogeneous. The statistical analyses were carried out using SAS.

Analyses of variance for all four species (T. cordata, $T$. euchlora, T. europaea, and T. platyphyllos) and for a group that included T. cordata, T. europaea, and T. platyphyllos revealed a significant species-related effect on dimensions. As representatives of the Tilia family in the environment in question, T. cordata, T. europaea, and $T$. platyphyllos can be treated in common. T. euchlora, which is differentiated by its lower growth rate (Table 1), is ignored in the data set and then in further analysis.

Regression analyses were conducted for T. cordata, $T$. europaea, and $T$. platyphyllo, collectively, to determine whether the relationships between age and 1) tree height, 2) trunk height, 3) trunk diameter, 4) crown base, and 5) crown radius of both unshaded trees and shaded trees (in avenues and rows) were linear $(Y=$ $\left.b_{1} d\right)$ or quadratic $\left(Y=b_{1} x+b_{2} d^{2}\right)$. [ $Y$ is the examined parameter (tree height, trunk diameter, etc.), $d$ is age, and $b_{1}$ and $b_{2}$ are constants.] Growth rate guides (Table 2) were obtained by differentiating the relationships found through regression analysis.

\section{RESULTS AND DISCUSSION}

The regression analyses revealed quadratic correlations for all relationships both for trees affected by shade and for unshaded trees (Table 3 and Figure 1).

The correlation between age and tree height $\left(r^{2}=\right.$ 0.97, $P=0.0001$ ) showed that height increases with age, to $19.5 \mathrm{~m}(64 \mathrm{ft})$ at an age of 101 years. Thus, in an urban growing environment, the height curve gives a reasonably certain picture of Tilia's height as a function of age in the interval 0 to 100 years.

The tree heights given by the relationships of this study were lower than those in the literature. For in-
Table 3. Growth formulas of Tilia cordata, T. europaea, and T. platyphyllos.

\begin{tabular}{llllll}
\hline$Y^{*}$ & $b_{1}$ & $b_{2}$ & $r^{2}$ & $P$ & $n$ \\
\hline Tree height & 0.3846 & -0.0019 & 0.9703 & 0.0001 & 299 \\
Trunk height & 0.1061 & -0.0006 & 0.9272 & 0.0001 & 227 \\
$\begin{array}{l}\text { Trunk diameter } \\
\text { Crown base }\end{array}$ & 0.8778 & -0.0033 & 0.9725 & 0.0001 & 288 \\
$\begin{array}{l}\text { Crown radius, } \\
\quad \text { unshaded }\end{array}$ & 0.1257 & -0.0005 & 0.9152 & 0.0001 & 229 \\
$\begin{array}{l}\text { Crown radius, } \\
\text { shaded }\end{array}$ & 0.1358 & -0.0008 & 0.9356 & 0.0001 & 463 \\
${ }^{*} Y=b_{1}+b_{2} d^{2} ; d=$ age. & & & &
\end{tabular}

stance, Johnson (1975) states that Tilia europaea attains

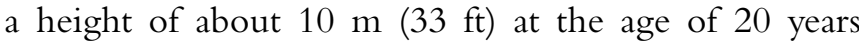
and that the tree can attain a height of up to $40 \mathrm{~m}(132$ $\mathrm{ft})$. This study shows that, in the urban environment, Tilia attains a height of only about $7 \mathrm{~m}(23 \mathrm{ft})$ after 20 years and a maximum height of about $20 \mathrm{~m}(66 \mathrm{ft})$ after 100 years.

Growth in height decreased steadily as age increased. According to the calculations, Tilia grows to about $5 \mathrm{~m}$ $(16 \mathrm{ft})$ during the first 15 years, whereas the height increase from 85 to 100 years is only about $0.5 \mathrm{~m}$ (20 in.).

The correlation between age and trunk diameter $\left(r^{2}=0.97, P=0.0001\right)$ shows that the expected trunk diameter after 100 years is about $55 \mathrm{~cm}$ (22 in.).

The correlation between age and trunk height $\left(r^{2}=\right.$ 0.97, $P=0.0001)$ shows that trunk height increases with age. The correlation between age and crown base shows that the crown base increases marginally with age $\left(r^{2}=0.92, P=0.0001\right)$. These values are expected in both cases, because the branching height and crown base are regulated by pruning of the lowest branches. In urban locations, these lowest branches frequently interfere with traffic; thus, they are often removed. Further crown lifting often occurs for aesthetic reasons.

The correlations between age and crown radius for both unshaded trees and shaded trees show that crown diameter increases with age. The $r^{2}$ assumed values of 0.95 and 0.94 , respectively. The coefficients of correlation largely coincide up to the age of about 45 years, at which time the growth rate of the crown radii of trees affected by shade flattens out. From that point on, shade (the effects of which depend on the distances between rows and plants) exerts a strong influence on crown radius, which, thereafter, only increases very slowly. 


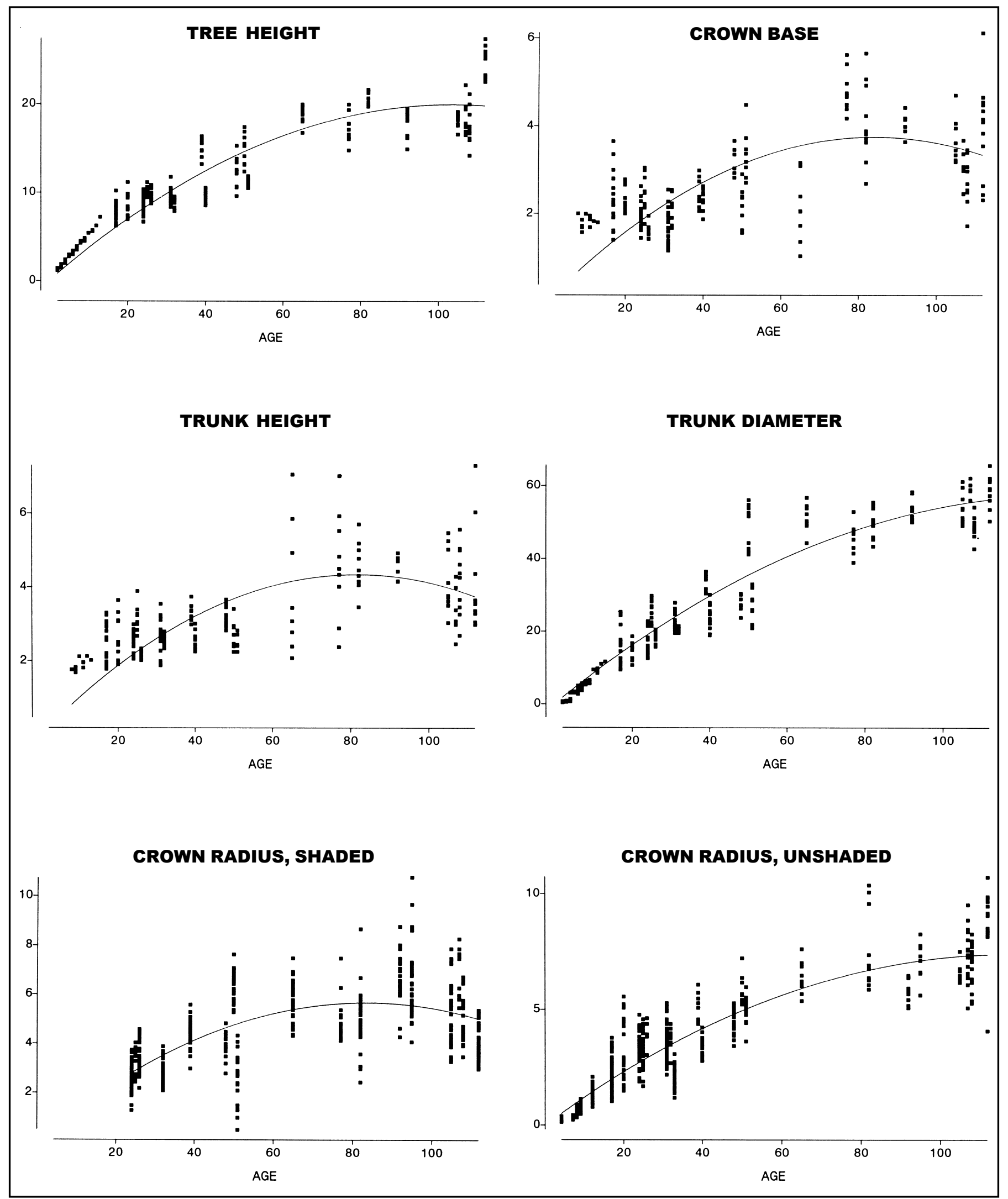

Figure 1. Tree age versus size parameters of Tilia cordata, T. europaea, and T. platyphyllos. 


\section{CONCLUSION}

In this study, we have described Tilia's growth from 0 to 100 years, with primary emphasis on the younger years because that is when planners traditionally attempt to forecast its growth.

The duration of the period for which it is actually possible to plan in urban environments presents us with a new problem. Many studies have shown that the average life span of urban trees is very short and can be as low as 10 to 15 years (Foster and Blaine 1978; Gilbertson and Bradshaw 1990; Nowak et al. 1990; Miller and Miller 1991). This study shows that within the actual life span of urban trees, it will be difficult to obtain the expected architectural and aesthetic function.

The new tools presented here make it possible to obtain a dynamic picture of the varying dimensions and visual impression of the trees over time.

With these functions, applications for dynamic illustrations can be made more realistically in urban environments using tools such as AutoCAD.

We described the Tilia species commonly used (except for $T$. euchlora) to prepare a simple planning tool for the most popular genus of urban tree in Denmark. The species-related differences encountered in the plantations were only minor and lacked significance in this context.

\section{LITERATURE CITED}

Foster, R.S., and J. Blaine. 1978. Urban tree survival: Trees in the sidewalk. J. Arboric. 4(1):14-17.

Gilbertson P., and A.D. Bradshaw. 1990. The survival of newly planted trees in inner cities. Arboric. J. 14: 287-309.

Johnson, H. 1975. The International Book of Trees (Danish version: Traernes Bog). Editor Aa. Andresan. Lademann 1975: 174-175, 287-288.

Miller, R.H., and R.W. Miller. 1991. Planting survival of selected street tree taxa. J. Arboric. 17(7):185-191.

Nowak, D.J., J.R. McBride, and R.A. Beatty. 1990. Newly planted street tree growth and mortality. J. Arboric. 16(5):124-129.

Acknowledgments. We thank Copenhagen's park districts, the Park Departments of Frederiksberg and Roedovre Local Council, the Danish Palaces and Properties Agency, Palaces and Properties Agency, Garnisons Cemetery,Vestre Cemetery, and the public building society, Socialt Boligbyggeri, for the great courtesy and helpfulness they showed when we were trying to obtain planting plans.

\author{
${ }^{1 *}$ Landscape Architect \\ Praestebakken 16 \\ DK-2610 Roedovre \\ Denmark \\ ${ }^{2}$ Ph.D., Research Landscape Architect \\ Danish Forest and Landscape Research Institute \\ Hoersholm Kongevej 11 \\ DK-2970 Hoersholm \\ Denmark \\ ${ }^{*}$ Corresponding author.
}


Résumé. Sur 331 arbres-Tilia cordata, T. europea, T. euclora et T. platyphyllos-localisés en environnement urbain, on a mesuré la hauteur de l'arbre, la hauteur du tronc, le diamètre du tronc, le diamètre de la couronne et le rayon de cime. Les analyses de régression ont révélé une corrélation quadratique entre l'âge et la dimension dans toutes les relations. Une formule de croissance ainsi que des taux de croissance ont été dérivées, et des courbes de croissance compilées. Les résultats peuvent être utilisés pour prévoir les dimensions physiques du tilleul en fonction du temps et de l'environnement, et aussi pour planifier et évaluer les conséquences de la plantation du tilleul sur le schéma de l'environnement urbain. Lorsque implantées dans une application de type CAD, ces relations peuvent fournir une base pour l'illustration dynamique d'un projet.

Zusammenfassung. Von 331 Bäumen aus urbanen Gebieten (Tilia cordata, europaea, euclora, platyphyllos) wurde die totale Höhe, Stammhöhe, Stammdurchmesser, Kronenbasis und -radius gemessen. Die Regressionsanalyse enthüllte quadratische Korrelationen zwischen Alter und Größe für alle Beziehungen. Wachstumsschemata und Wachstumsraten wurden und Wachs- tumskurven erstellt. Die Ergebnisse können zur Vorhersage der physikalischen Dimension von Tilia als Funktion über die Zeit und Umwelt genutzt werden und damit auch für Planung und Untersuchung der Auswirkungen von Lindenpflanzungen in urbanen Gebieten. Wenn diese Beziehungen als CAD Anwendung implementiert werden, können sie die Basis für eine Dynamische Illustration eines Projektes bilden.

Resumen. Se midió en 331 árboles (Tilia cordata, T. europaea, T. euclora, y T. platyphyllos) que crecen en ambientes urbanos, la altura del árbol, altura del tronco, diámetro del tronco, base de la corona y radio de corona. Los análisis de regresión revelaron correlación cuadrática entre la edad y el tamaño para todas las relaciones. Fueron derivadas las fórmulas de crecimiento y las tasas de crecimiento y de allí se compilaron curvas de crecimiento. Estos resultados pueden ser usados para pronosticar las dimensiones fisicas de los Tilia, como funciones de tiempo y ambiente y con ello para la planeación y evaluación de las consecuencias de plantaciones con árboles de Tilia en ambientes urbanos. Cuando se implementan como una aplicación en Diseño Asistido por Computadora (CAD), estas relaciones pueden formar las bases para la ilustración dinámica de un proyecto. 